\title{
UM DIÁRIO ENTRE O CÍVICO E O ESTÉTICO: AS REFLEXÕES DE GuSTAVO COCHET, DURANTE OS anos da GUerRa Civil Espanhola
}

\author{
Margareth dos Santos
}

Durante os anos da Guerra Civil Espanhola, o pintor argentino Gustavo Cochet dedicou-se a três grandes atividades: à luta contra o fascismo e a favor da República espanhola, à sua série de gravuras intitulada Caprichos e à escritura de seu Diario de un pintor (1941). Neste, discorreu acerca de suas concepções sobre arte, política e sobre a natureza do momento que lhe tocou viver. Ao percorrer suas páginas, advertimos como um registro considerado, num primeiro momento, como uma forma de discurso íntimo por excelência, converte-se em um espaço de debate sobre sua arte, sobre cultura e sobre a condição humana em meio a um conflito de dimensões desastrosas: a Guerra Civil Espanhola. Em suas linhas, contemplamos uma palavra marcada por contornos ensaísticos - em sua liberdade e irregularidade -, em que falar de si equivale, necessariamente, a falar do outro, uma vez que, ao longo de seu percurso reflexivo, o espaço da intimidade vai se misturando ao âmbito coletivo, num jogo de justaposições que põe em cheque os limites entre o papel cívico do homem e o de sua arte e seu pensamento.

Elaborado de forma fragmentária, entre a reflexão íntima e a pública, o Diario de un pintor se divide em dois grandes períodos históricos: o da Guerra Civil Espanhola - momento do qual nos ocuparemos - e o da volta de Cochet ao solo argentino, nos anos 1940. Conformado à maneira de aforismos, ou seja, numa escritura pautada pela apreensão da realidade e preocupada por oferecer ao leitor determinadas reflexões, 
o Diario estrutura-se de modo conciso e incisivo. Em alguns momentos, seu texto parece evocar anotações feitas no calor de uma época em que a razão objetiva parecia ter desaparecido e refugiara-se em um campo de desatinos, sob o furor que um conflito armado supõe.

No entanto, à medida que o lemos, vemos como sua composição sucinta contradiz a ânsia e cristaliza-se em fragmentos que apresentam em si uma suficiência de significado, revelando no fragmentário uma forma idônea para refletir sobre posições éticas e estéticas em meio a um período histórico convulso.

Imiscuídas a suas ponderações, o pintor disseminou gravuras em meio a seu texto, e a força dessas imagens em preto e branco institui um diálogo imperativo entre a palavra fragmentada e as diminutas figuras espalhadas pelo diário. As trinta e sete gravuras expõem a maneira como o pintor enxerga seu lugar no mundo e sua conduta, pautada por duas grandes questões: a contraposição a alguns pecados capitais, como a avareza, o egoísmo, a luxúria e a gula, que empequenecem o homem, e a afirmação de um lema de vida calcado na esperança, na cultura, na arte e no compromisso libertário.

Frente a essas demandas, chama a atenção como o pintor exibe suas crenças: por meio de uma escritura irregular e híbrida, situada entre o desenho autobiográfico do diário, a meditação sócio-histórica, a relação imagem-texto e a argumentação estética. Instigados por essa conjunção, propomos, neste artigo, ler o papel dessa escrita a partir da ideia de que Cochet, com seu diário, expõe a figuração de um compromisso assumido com as questões prementes da realidade circundante, sem que para isso abandone uma crítica salpicada por tentativas de compreensão do que viveu, gravou, leu e viu em distintas dimensões.

Aliada a essa leitura está a discussão em torno do diálogo estabelecido entre o diário e a produção pictórica de Cochet nos anos da Guerra Civil. Portanto, não nos centraremos nas gravuras disseminadas ao longo do diário, símbolos do modus vivendi de Cochet, mas sim, na série Caprichos. Essa opção de debate justifica-se pela possibilidade de dar um passo em direção à compreensão da crítica de Cochet, posto que acreditamos que ambas as conformações esclarecem o movimento do pensamento do pintor.

A fim de elucidar esse movimento, exploraremos duas vias de aproximação: uma pautada pelas discussões sobre o ensaio propostas por Adorno (2008), Berardinelli (2011) e Starobinski (2011), e a outra, fincada 
nas relações entre palavra e imagem. O apelo a esses autores deve-se aos paralelos que podemos traçar entre a arquitetura do texto de Cochet e a especificidade do ensaio como forma de organização textual.

Em sua argumentação sobre tal especificidade, Adorno contrapõe a natureza do texto ensaístico às regras cartesianas de estudo de um objeto. Segundo o crítico, o ensaio "desafia" a necessidade de definir conceitos, de sistematizá-los, de classificá-los. Essa contraposição realiza-se porque o ensaio atua a partir de uma "autonomia de exposição", e dita autonomia proporciona maior liberdade ao estudo de um ou mais objetos:

O ensaio não segue as regras do jogo da ciência e da teoria organizadas, segundo as quais, como diz a formulação de Spinoza, a ordem das coisas seria o mesmo que a ordem das ideias. Como a ordem dos conceitos, uma ordem sem lacunas, não equivale ao que existe, o ensaio não almeja uma construção fechada, dedutiva ou indutiva (ADORNO, 2008, p. 25).

É a partir dessa afirmação de uma estrutura aberta e assistemática que se articula nossa tentativa de demonstrar a convergência entre os "aforismos de contornos ensaísticos" (BERARDINELLI, 2011, p. 25) do diário de Cochet e sua série Caprichos, ou seja, um diálogo interartístico sustentado por uma escritura "com a qual comunicamos pensamentos, juízos, reflexões, interpretações [...] como um tipo de escrita direta, mas ao mesmo tempo sofisticada e indócil ou, ao contrário, flexível e maleável" (p. 25).

No âmbito da segunda via de exploração do texto de Cochet, a análise do diálogo entre duas produções concomitantes guiará nossa discussão: a parcela do diário escrito durante a Guerra Civil espanhola e a série de gravuras Caprichos. Como veremos, uma forma enlaça-se à outra, de modo a constituir um discurso textual e imagético que tenta dar conta da contenda e de suas implicações, sem se furtar ao exame de um tempo vivido, pensado e gravado de maneira indócil e discursivamente fraturada:

\footnotetext{
O ensaio pensa em fragmentos, uma vez que a própria realidade é fragmentada; ele encontra sua unidade ao buscá-la através dessas fraturas, e não ao aplainar essa realidade fraturada. A harmonia uníssona da ordem lógica dissimula a essência antagônica daquilo sobre o que se impõe. A descontinuidade é essencial ao ensaio, seu assunto é sempre um conflito em suspenso (ADORNO, 2008, p. 35).
}

Esperamos que ambos os caminhos, combinados, revelem um pensamento situado entre uma postura ética e estética, libertária e comprometida. 
Uma dessas posições pode ser aferida em 1936, quando Cochet (1932, p. 89) anota em seu Diario de un pintor a seguinte afirmação: "En mi oficio de pintor o grabador huyo de lo vacuo y lo grandilocuente para acercarme lo más posible a lo comprimido y agudo". Sem dúvida, essa declaração do artista estaria em consonância não apenas com seu conceito de arte, em que a contenção rimava com expressão, mas também com o contexto conturbado pelo qual passava: a Guerra Civil espanhola.

Vivendo em Barcelona com sua família, em um dos maiores centros de resistência em meio ao conflito, Cochet usou sua arte e sua palavra como armas contra o fascismo e a favor da revolução espanhola. Portanto, acercar-se de sua experiência e atuação pressupõe reconhecer a relevância do papel de artistas latino-americanos que também se sentiram compelidos a lutar pelo ideal republicano junto a tantos outros personagens de diversa origem.

Filho de pai francês e mãe criolla, o artista resumiria assim sua biografia:

¿Cuál es su nacionalidad? En la Argentina, provincia de Santa Fe, y a orillas del Paraná nací, hijo de un francés rubicundo y de una criolla santafecina. Entre Cataluña y Francia he pasado la mitad de mi vida; en la primera de éstas conocí el amor, aprendí a trabajar, fui feliz. En Francia despertóse mi herencia espiritual paterna, mi cultura es francesa. De la Argentina llevo en lo más hondo de mi ser, como marca indeleble, la llanura de la pampa que significa en mí: atavismos de horizontes sin límites y de sentimentalismo profundo. Así que: ¿cuál es su patria, amigo?... Pues, cualquiera de las tres naciones o las tres a la vez (COCHET, 1941, p. 44).2

Esse breve resumo biográfico de Cochet pode nos servir como coordenadas para pensarmos a arte desse argentino, cujo forte caráter libertário foi alimentado desde muito cedo: no seio de sua família mestiça e em sua formação intelectual, cujo primeiro momento de inflexão ocorreu

\footnotetext{
1 "Em meu ofício de pintor ou gravador, fujo do vácuo e do grandiloquente para aproximarme ao máximo do condensado e agudo.” Todas as traduções do espanhol são nossas.

2 "Qual é a minha nacionalidade? Na Argentina, província de Santa Fé, e nas margens do rio Paraná, nasci, filho de um francês meio ruivo e de uma mestiça de Santa Fé. Entre Catalunha e França passei a metade da minha vida; na primeira destas, conheci o amor, aprendi a trabalhar, fui feliz. Na França se despertou minha herança espiritual paterna, minha cultura é francesa. Da Argentina conservo o mais profundo do meu ser, como uma marca indelével, a planície do pampa, que significa em mim: idiossincrasias de horizontes sem limite e de sentimentalismo profundo. De modo que: qual é a minha pátria, amigo? ... Pois, qualquer uma das três nações ou as três ao mesmo tempo".
} 
aos dezoito anos, quando o jovem Gustavo saiu do pequeno povoado de Maciel, onde nascera em 1894, rumo a Rosario com o intuito de estudar arte.

Ali, conviveu intensamente com ativistas libertários e movimentos anarcossindicalistas. A partir desses contatos, não é de se estranhar que Cochet tenha vinculado sua formação acadêmica a artistas locais que nutriam ideais anarquistas, tampouco se estranha que, na condição de franco-argentino, tenha se engajado pela luta contra o golpe de estado de 1936 e a favor do governo legítimo da II República espanhola.

Não obstante, para compreender essa opção de vida e de causa, é necessário que ampliemos um pouco as pistas biográficas de Cochet, até o momento de sua atuação na Guerra Civil Espanhola: depois de três anos estudando em Rosario e com o desejo de conhecer a terra natal de seu pai, a França, o pintor partiu em navio, rumo à Europa. Mas, antes de chegar a Paris, aportou em Barcelona em 1915 - em plena I Guerra Mundial - onde permaneceu até 1921.

Em Barcelona estudou e trabalhou como restaurador para o marchand Josep Dalmau, figura famosa por seu apoio às vanguardas internacionais e um dos primeiros a organizar, em 1912, uma exposição sobre a arte cubista na Europa. E foi em meio à efervescência das vanguardas, que Cochet experimentou o segundo momento de inflexão em sua formação como artista e cidadão do mundo: teve contato com inúmeros artistas que expunham nas Galeries Dalmau, tais como, Joaquín Torres García, Joan Miró e intelectuais que frequentavam o círculo de uma burguesia catalã próspera e inclinada às artes. Podemos afirmar que sua participação nesses debates estéticos se prolongou com sua estadia em Paris, para onde partiu com sua esposa, a catalã Francisca Alfonso, companheira de toda uma vida.

Uma vez em Paris, nos idos de 1921, cumpriu o serviço militar na condição de filho de pai francês e, um ano depois, já com ateliê montado, nasceria seu filho Fernando. Da confluência dessas duas geografias artísticas e sentimentais, emergiu um artista mais maduro, consciente de sua formação e convicções:

A una feliz conjunción debo mi formación artística: Barcelona y París. En la primera me hice al trabajo, al sentido artesano del oficio; como, saturando mi cuerpo con la savia de los pinos, por la montaña, aprendí a amar la naturaleza. 
Um diário entre o cívico e o estético: as reflexões de Gustavo Cochet, durante os anos da... - 832

arís comprendí el sentido heroico. Allí la llama del ideal se incendió para mientras dure mi vida (COCHET, 1941, p. 89). ${ }^{3}$

Diante dessa declaração do pintor, é difícil não atentar para certas afinidades entre Cochet e Antonio Machado. Afinal, o grande poeta espanhol também afiançou um compromisso com a imagem de um artista de caráter cívico e negou a representação do boêmio. Em Campos de Castilla, Machado (2002, p. 102) nos propõe que sonhemos de olhos abertos e que o poeta se posicione frente ao mundo e com ele estabeleça um diálogo, a partir da elaboração de uma voz capaz de conjugar intimidade e coletividade:

Y al cabo, nada os debo; debéisme cuanto he escrito.

A mi trabajo acudo, con mi dinero pago

el traje que me cubre y la mansión que habito,

el pan que me alimenta y el lecho en donde yago. ${ }^{4}$

Se tomarmos como ponto de partida essa conjugação, veremos como ambos, poeta e pintor, buscaram um difícil equilíbrio entre o diálogo com a realidade e a compreensão de que a arte se configura como um exercício cívico. Na corda bamba entre o público e o privado, o coletivo e o individual, pode-se dizer que Cochet e Machado lançam um olhar indagador que rompe com a figura do artista boêmio e esteta para buscar a reflexão, a ética e a voz de uma consciência cívica. Ambos impõem vínculos com a realidade, uma vida ativa, em que se possa escapar da esterilidade de mundos abstratos. Ao negar qualquer tipo de escapismo, forjam uma estética em que a preocupação humanística se sobressai:

$\mathrm{Al}$ revelar mis ideas y mis pensamientos, que giran casi siempre en torno de un mismo tema, no lo hago con la pretensión de crear nuevos sistemas filosóficos o nuevas religiones; lo hago con el mismo sentimiento que pinto una tela o acaricio la cara de un niño; sinceridad y buena fe. No me guía otra cosa que acercarme a la verdad. ¡Ojalá logre algo y habré contribuido con ello a la eterna aspiración de la humanidad! Barcelona, 1936 (COCHET, 1941, p. 72).5

\footnotetext{
${ }^{3}$ A uma feliz conjunção devo a minha formação artística: Barcelona e Paris. Na primeira me formei no trabalho, no sentido de artesão do ofício; como, saturando meu corpo com a seiva dos pinheiros, pela montanha, aprendi a amar a natureza. Em Paris compreendi o sentido heroico. Ali a chama do ideal se encendeu para enquanto dure minha vida.

4 "Enfim, nada lhes devo; /devem-me o que escrevi. /A meu trabalho acudo, com meu dinheiro pago /a roupa que me cobre e a mansão que habito, /o pão que me alimenta e o leito onde jazo."

5 "Ao revelar minhas ideias e meus pensamentos, que giram quase sempre em torno de um mesmo tema, não o faço com a pretensão de criar novos sistemas filosóficos ou novas
} 
Essa mesma preocupação de Cochet faz eco às reflexões machadianas:

- La poesía es - decía Mairena - el diálogo del hombre, de un hombre con su tiempo. Eso es lo que el poeta pretende eternizar, sacándolo fuera del tiempo, labor difícil y que requiere mucho tiempo, casi todo el tiempo de que el poeta dispone (MACHADO e MACHADO, 1973, p. 743). ${ }^{6}$

São vozes que se enfrentam em circunstâncias turbulentas, ao mesmo tempo que tentam se firmar em seus respectivos fazeres artísticos, são vozes de sujeitos despidos de heroísmo, que fogem da falta de vínculos com a sociedade e que conseguem estabelecer contato entre a vida e a estética.

Entre artistas existen los llamados bohemios, si es verdad, el bohemio es un ente simpático, buen vividor, alegre, espiritual, buen conquistador de mujeres, pero que igual puede ser pintor, músico o torero, escritor o gitano, saltimbanqui o bufón; será en el mejor de los casos el "dilettanti" sensible, que disfruta pintando o escribiendo, pero no será nunca el artista verdadero, que con penas y trabajos busca la razón de su arte, en lo más profundo de su vida; y la vida no dará nunca gratuitamente, sino por el amor y el sacrificio (COCHET, 1941, p. 101). ${ }^{7}$

Esses vínculos estéticos e éticos, plasmados em o Diario de un pintor, caracterizam-se por uma longa sequência de reflexões, crônicas e frases à maneira de aforismos, em que o artista circunscreve sua vivência nos anos da Guerra Civil Espanhola. Talvez aqui caiba aclarar que não manejamos a noção de aforismo como "uma sentença breve e indiscutível, que resume uma doutrina” (MACHADO, 1977, p. 39), mas sim, como "texto curto e sucinto, fundamento de um estilo fragmentário e assistemático [...] relacionado a uma reflexão de natureza prática ou moral" (HOUAISS, 2009, p. 36). Portanto, embora o Diario esteja repleto de sentenças breves,

religiões; o faço com o mesmo sentimento que pinto uma tela ou acaricio o rosto de uma criança; sinceridade e boa-fé. Espero que consiga algo e terei contribuído com isto à eterna aspiração da humanidade!"

6 "A poesia é - dizia Mairena - o diálogo do homem, de um homem com o seu tempo. Isso é o que o poeta pretende eternizar, tirando-o fora do tempo, labor difícil e que requer muito tempo, quase todo o tempo de que o poeta dispõe."

7 "Entre artistas existem os chamados boêmios, se for verdade, o boêmio é um ser antipático, bon vivant, alegre, espirituoso, conquistador de mulheres, mas também pode ser pintor, músico ou toureiro, escritor ou cigano, saltimbanco ou bufão; será, no melhor dos casos, o 'diletante' sensível, que desfruta pintando ou escrevendo, mas não será nunca o artista verdadeiro, que com sofrimentos e trabalhos busca a razão de sua arte, no mais profundo de sua vida; e a vida não dará nunca gratuitamente, se não pelo amor e pelo sacrifício." 
não há nele um caráter indiscutível ou doutrinário (ainda que ele esteja impregnado de um fundo pedagógico), mas encontra-se nele um estilo fragmentário e assistemático, conexo à forma do ensaio:

Portanto a modernidade, sobretudo no século XX, reservou uma centralidade estratégica para a forma ensaística. $\mathrm{O}$ século da crise dos gêneros não poderia deixar de pedir ajuda ao mais crítico e instável dos gêneros, o gênero literário da reflexão, da interpretação e da autoconsciência (BERARDINELLI, 2011, p. 27).

É uma escritura limiar, na medida em que nutre em seu interior distintas formas de expressão, que por sua vez, enredam-se em temporalidades e espacialidades embaralhadas, opiniões polêmicas, meditações cortantes e sintagmas lapidares. Nesses redutos textuais, as tomadas de posição de Cochet frente ao conflito conversam tanto com seu tempo e seus pares, quanto com o fazer artístico da época:

El arte, siempre, en todos sus momentos de reiniciación, no se basa nunca en leyes estéticas o cánones establecidos, sino en lo intuitivo personal, en un amor poético de la naturaleza, de los seres y cosas que en ella existen, como asimismo apoyados o inducidos en la exaltación de nuevos ideales, de nuevas creencias. De modo que las llamadas escuelas de vanguardia en estos momentos, son casi siempre la expresión suprema de una supercultura, es decir no representan un renacimiento, sino el proceso de un fin (COCHET, 1941, p. 75). ${ }^{8}$

E em suas linhas controversas, haverá espaço tanto para debater com intelectuais e artistas contemporâneos ao conflito espanhol, como também para chorar a perda do admirado poeta Machado, tido como um exemplo para Cochet e cuja morte representou um marco na derrota da guerra civil:

El entierro: un refugiado, un extranjero, un rojo. A los pescadores de Collioure, gentes humildes y buenas, no les preocupaba tal cosa. Sabían que era poeta, un hombre en desgracia, perdido y derrotado lejos de su tierra, eso era más que suficiente para que ellos se conmovieran en lo más íntimo de sus corazones y le acompañaran con profunda pena. El alcalde de Collioure, al pueblo y a los potentados, lo despidió con sentidas y emocionadas palabras.

\footnotetext{
8 "A arte, sempre, em todos os seus momentos de reinício, não se baseou nunca em leis estéticas ou cânones estabelecidos, mas no intuitivo pessoal, no amor poético da natureza, dos seres e coisas que nela existem, como também apoiados ou induzidos na exaltação de novos ideais, de novas crenças. De modo que as chamadas escolas de vanguarda nesses momentos são quase sempre a expressão suprema de uma supercultura, ou seja, não representam um renascimento, mas o processo de um fim."
} 
Y en mi pecho se ahogó una pena muy honda.

Collioure, 1939 (COCHET, 1941, p. 73). ${ }^{9}$

Ao término da Guerra Civil Espanhola, os Cochet cruzaram a fronteira entre a Espanha e a França, como Antonio Machado, como milhares de espanhóis em êxodo. Graças à descendência francesa de Cochet, a família conseguiu exilar-se na França e dali foi repatriada à Argentina, naquele mesmo ano, onde se estabeleceu definitivamente. Ainda que à salvo dos campos de concentração montados pelos franceses, Cochet não deixaria de denunciar a condição atroz a que milhares de espanhóis se viram submetidos:

Privilegiado por mi ascendencia francesa, me salve de los campos de concentración en Francia, después de la huida de España. A menudo iba a ver artistas, poetas, antiguos compañeros que junto a tantos otros miles de refugiados, compartían tan grande infortunio, vigilados por negros senegaleses, amontonados tras los alambres de púas, tratados como si no fuesen seres humanos.

Argelés, marzo de 1939 (COCHET, 1941, p. 79). ${ }^{10}$

Sem dúvida, a denúncia dessas ações, conectada ao resgate dessa dor, de perspectivas e de afinidades do pintor argentino com artistas e intelectuais que lutaram pela causa espanhola passam pela necessidade de recuperar as relações de seus escritos e de sua arte, em especial, de sua série de gravuras Caprichos, composta nos duros anos da contenda. Através de seu diário e desse conjunto, o gravador pôde mover-se por terrenos estéticos em que seu olhar analítico se revelou como elemento deflagrador de suas concepções do combate e suas implicações. Identificado com a causa republicana, o artista declarou em 1936 que deixara de lado a pintura para se tornar um miliciano a mais:

\footnotetext{
9 "O enterro: um refugiado, um estrangeiro, um comunista. Aos pescadores de Collioure, pessoas humildes e boas, não lhes preocupava tal coisa. Sabiam que era poeta, um homem em desgraça, perdido e derrotado longe de sua terra, isso era mais que suficiente para que eles se comovessem no mais íntimo de seus corações e o acompanhassem com profunda dor. O prefeito de Collioure, ao povo e aos poderosos, despediram-se dele com sentidas e emocionadas palavras. /E no meu peito se oprimiu uma dor muito profunda. /Collioure, 1939."

1o "Privilegiado por minha ascendência francesa, salvei-me dos campos de concentração na França, depois da fuga da Espanha. Frequentemente ia ver artistas, poetas, antigos companheiros que junto a tantos outros milhões de refugiados, compartilhavam tão grande infortúnio, vigiados por negros senegaleses, amontoados atrás das cercas de madeira, tratados como se não fossem seres humanos. /Argelés, março de 1939."
} 
Um diário entre o cívico e o estético: as reflexões de Gustavo Cochet, durante os anos da... - 836

El 19 de julio de 1936 cerré las puertas de mi taller en Barcelona y allí quedaron inconclusas las obras que estaban en curso de ejecución; ¿en qué podían servirles mis pinturas al pueblo en armas en su magna lucha? En nada absolutamente. Me consideré entonces un miliciano más... (COCHET, 1941, p. 105). ${ }^{11}$

No entanto, essa declaração não seria de todo verdadeira, pois, ainda que Cochet tenha abandonado a pintura, naquele mesmo ano começaria a dedicar-se à gravura como forma de expressão idônea para configurar o conflito com a sobriedade do traço em preto e branco e a minúcia que requeria uma guerra civil. Simultaneamente ao labor artístico, exerceu o cargo de Comisario de Propaganda del Casal de la Cultura de Barcelona, contribuindo com ilustrações que acompanhavam artigos da imprensa anarquista, como os editados na revista Tierra y Libertad, discursos públicos e locuções radiofônicas.

Quiero que la imagen que yo evoco sea una acusación lapidaria, un llamado a los hombres y a las mujeres, un llamado no de clemencia, pero sí de justicia y de equidad, para que la sangre que salpica los muros de las ciudades y humedece la tierra de los campos de batalla, sea fructífera; para que las cárceles y prisiones que se destruyen hoy, lo sean para siempre y no para crear otras en su lugar; que los ejércitos sanguinarios, que destruimos hoy, lo sean para siempre y no para crear otros en su lugar, que los privilegios, las castas, los mandatarios y especuladores que destruimos hoy, lo sean para siempre y no para crear otros en su lugar. (6 pensamientos extraídos de una alocución por "Radio Barcelona" en la navidad de 1936 (COCHET, 1941, p. 104). ${ }^{12}$

No rastro dessas atuações combativas, unindo imagem e palavra, o pintor compôs sua série Caprichos, inspirada em outras três séries de gravuras: Les misères et malheurs de la guerre, de Jacques Callot (1633), Los

\footnotetext{
" "Em 19 de julho de 1936, fechei as portas de meu ateliê em Barcelona e ali ficaram inconclusas as obras que estavam sendo executadas; para que poderiam servir-lhes minhas pinturas ao povo armado em sua magna luta? Para nada absolutamente. Me considerei então mais um miliciano...”

12 "Quero que a imagem que eu evoco seja uma acusação lapidar, um chamado aos homens e às mulheres, um chamado não de clemência, mas de justiça e de equidade, para que o sangue que salpica os muros das cidades e umedece a terra dos campos de batalha, seja frutífero; para que os cárceres e as prisões que são destruídos hoje, o sejam para sempre, e não para serem criadas outras em seu lugar; que os exércitos sanguinários, que destruímos hoje, o sejam para sempre e não para serem criados outros em seu lugar, que os privilégios, as castas, os mandatários e especuladores que destruímos hoje, o sejam para sempre, e não para serem criados outros em seu lugar (6 pensamentos extraídos de uma locução pela 'Radio Barcelona' no Natal de 1936."
} 
caprichos (1799) e Los desastres de la guerra (1810), ambas de Francisco de Goya y Lucientes. Dita filiação encontra-se atestada no frontispício da primeira gravura da série (Figura 1):

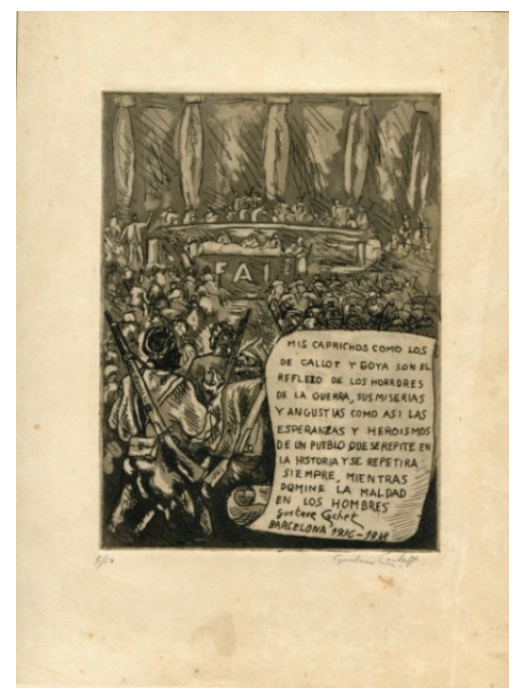

Figura 1. Reprodução da gravura Mis caprichos... (COCHET, 1936-1938).

Fonte: Imagem cedida pelo Museo Gustavo Cochet.

O texto incluído na imagem funciona como uma carta de intenções da série, ao mesmo tempo que a filia à tradição capitaneada pelas figuras de Callot e Goya, que igualmente retrataram o horror da guerra. No entanto, apesar do frontispício de Cochet explicitar essa dupla vinculação, acreditamos que suas afinidades pendem especialmente para o universo goyesco, uma vez que ambos se aproximam tanto pelo uso da técnica de água-forte de maneira inovadora, como pelo tratamento fragmentário da guerra. Ademais, a coincidência de mensagens do frontispício do artista argentino aproxima-o de maneira incontestável ao pintor aragonês:

Fatales consecuencias

de la sangrienta guerra en España con Buenaparte

Y otros Caprichos enfáticos

En 85 estampas

Inventadas, dibuxadas y grabadas

Por el pintor original

D. Francisco de Goya y Lucientes 
En Madrid

(GOYA Y LUCIENTES, 1799). ${ }^{13}$

O texto escrito de próprio punho por Goya indica o assunto e a natureza das estampas: entre a imaginação e a história, ele anuncia uma série original, cujo intuito é o de refletir sobre a Guerra de Independência, numa cronologia que abarca desde o cerco a Saragoça, em junho de 1808, passa pela ofensiva francesa e pelas imagens que retratam a grande fome que assolou Madri em 1811, e finaliza com uma etapa conhecida como Caprichos enfáticos, em que atacou duramente a Restauração de Fernando VII.

Em seus Caprichos enfáticos, Goya fez críticas que a série de Cochet parece repercutir: nas gravuras de ambos os artistas há ataques à Igreja, a explicitação de posições duras frente ao conflito bélico e críticas aos poderosos corruptos que se aproveitam dos mais fracos em um momento de profunda instabilidade.

Ademais, o frontispício nos faz lembrar alguns dos movimentos do diário de Cochet: um pensamento de fundo pedagógico, atado a uma leitura da tradição viva e, ao mesmo tempo, cívica, que poderia aproximarse, ainda que obliquamente, à forma do ensaio: "o ensaísta pode se exprimir alternadamente de maneira idiossincrática ou anárquica, ou tecendo estratégias intelectuais inspiradas por uma 'missão' pública, pela responsabilidade pedagógica e civil” (BERARDINAELLI, 2011, p. 26).

Essa "missão" pública dá o tom da filiação de Cochet a Goya e Callot, por meio de seu caráter humanístico e civil. Não obstante, é preciso asseverar que não atribuímos a escolha do título do conjunto de gravuras do artista argentino à série Los caprichos, de Goya, como muitos críticos creem, mas sim à parcela final de Los desastres de la guerra, do mesmo artista. Nossa afirmação justifica-se pelo caráter das estampas de Cochet, que primam por uma tendência mais realista que fantástica. Se nossa ponderação estiver correta, o título de Cochet estaria ligado a esse exame veemente de um momento histórico convulso, e não ao mundo fantástico (e igualmente crítico, é certo) dos caprichos goyescos.

Goya, el genial artista aragonés, encarna estos dos aspectos, la España trágica y la España poética y de hondo sentir; cuando en sus aguafuertes cuenta los horrores

\footnotetext{
13 "Fatais consequências / da sangrenta guerra na Espanha com Bonaparte /E outros Caprichos enfáticos /Em 85 estampas /Inventadas, desenhadas e gravadas /Pelo pintor original /D. Francisco de Goya y Lucientes /Em Madrid."
} 
de la guerra, al lado del salvaje y cruel verdugo, que destroza el cuerpo de su víctima, están losárboles, las plantas, el cielo, las montañas de una belleza y poesía infinita. Goya sabía que el crimen más horrendo y terrible, puede cometerse en medio de un paisaje divino, lleno de flores y hermosos pájaros, cuyos trino y gorjeos contrastan con los ayes de las víctimas (COCHET, 1941, p. 104).14

Por meio das escolhas textuais e imagéticas de Cochet, podemos entrever como o pintor argentino exercita sua originalidade ao captar o sentido moral e libertário da série goyesca para convertê-la em uma representação própria do momento histórico, anunciado na estampa e em seu diário. Ademais, o texto do frontispício aproxima-se de uma caligrafia própria também, como bem assinala Laura Karp Lugo (2011, p. 4):

El afán de claridad llevó a Cochet a recurrir sistemáticamente a la palabra para explicar la escena representada. De modo que, aunque manteniendo su autonomía formal, cada estampa lleva grabada en el margen inferior una leyenda que guía la interpretación. El diálogo creado entre lo textual y lo visual acentúa el impacto del mensaje. ${ }^{15}$

Vale dizer que a simbiose entre título e imagem era algo caro a Goya e, em Cochet, essa preocupação parece repetir-se, já que o gravador argentino recorre a algo supostamente em "desuso" na arte do século XX: o frontispício. Lançar mão dessa forma indica, de antemão, sua negativa a modismos, e uma vinculação e intenção moral claras. E essas duas escolhas reafirmam uma relação entre texto e imagem vinculada energicamente a seu diário:

A menudo me llama la atención cuando al hablárseme teóricamente del arte, se mentan principios y reglas estéticas que coinciden con lo que yo ya sabía.

Pero por haberlo hecho y no leído (COCHET, 1941, p. 10). ${ }^{16}$

${ }_{14}$ "Goya, o genial artista aragonês, encarna esses dois aspectos, a Espanha trágica e a Espanha poética e de profundo sentir; quando em suas águas-fortes conta os horrores da guerra, ao lado do selvagem e cruel carrasco, que destroça o corpo de sua vítima, estão as árvores, as plantas, o céu, as montanhas de uma beleza e poesia infinita. Goya sabia que o crime mais horrendo e terrível pode ser cometido em meio a uma paisagem divina, cheia de flores e formosos pássaros, cujos canto e gorjeios contrastam com os ais das vítimas."

15 "O afã de clareza levou Cochet a recorrer sistematicamente à palavra para explicar a cena representada. De modo que, ainda que mantivesse sua autonomia formal, cada estampa leva gravada na margem inferior um título que guia a interpretação. O diálogo criado entre o textual e o visual acentua o impacto da mensagem."

16 "Com frequência me chama a atenção quando, ao me falarem teoricamente de arte, criam-se princípios e regras estéticas que coincidem com o que eu já sabia. Mas por tê-lo feito, e não lido." 
Ao instaurar uma relação textual e imagética e ao invocar uma filiação que se desloca temporalmente, Cochet não apenas estabelece uma conexão entre pensamento e ação, como realiza uma leitura ativa de si e da tradição. E, ao fazê-lo, reivindica uma relação diversa com o tempo, pois transpassa uma distância temporal de dois séculos, aproximando duas épocas por meio de outra lógica temporal, a da arte e da crença em um ideal. Essas duas grandes vertentes permitem que Cochet retome o passado e o reconfigure no presente, num movimento de valorização dinâmica do passado, como diria Leyla Perrone-Moisés (1982).

Esse movimento dinâmico pode ser observado na gravura-prólogo. Nela, entrevemos a imagem de uma reunião de militantes. A sigla FAI, da Federación Anarquista Ibérica, situada ao fundo da cena, permite identificar a mesa central da assembleia, em que dirigentes da federação presidem o encontro. Cercando essa mesa, uma multidão de personagens se agita, entre eles, destacam-se, em primeiro plano, três soldados com armas nos ombros. A posição de costas para o espectador cria uma perspectiva que nos situa no mesmo patamar dos militantes, instaurando uma aura de conclamação à cena. Num jogo entre o coletivo e o individual, entre uma cena panorâmica e o close-up, Cochet desloca levemente a perspectiva renascentista ao desrespeitar a organização da cena em uma pirâmide visual, ao jogar com tamanhos e proporções que se embaralham na imagem, como se pode constatar na articulação entre a sigla FAI, os milicianos em destaque e o frontispício.

Para chamar a atenção do espectador para distintas instâncias da gravura, Cochet conjuga elementos que se complementam: a inclinação ideológica, a entrega a uma causa e a mensagem que denuncia, filia e congrega. Portanto, em consonância com a linha adotada em seu Diario, cujo compromisso com uma causa se faz patente.

Esse espírito conclamatório, durante a guerra civil, plasmou-se tanto na luta pelo território, como pela afirmação artística, na qual vemos um Cochet participando ativamente das ações culturais praticadas pela Confederación Nacional de Trabajadores (CNT) e pela FAI. Não só os intelectuais, mas também os milicianos eram chamados à valorização da luta pelo território republicano e pelo patrimônio artístico cultural espanhol:

Gustavo Cochet fueel presidentedela Secciónde Bellas Artes dela Confederación Nacional de Trabajadores (CNT), organización anarcosindicalista, perteneciente a la Federación Anarquista Ibérica (FAI). Su compromiso 
con el momento histórico lo situó en un trabajo dirigido hacia un cambio transcendente, promoviendo el libre pensamiento, la toma de conciencia de la unidad y solidaridad entre los hombres como único camino para construir una sociedad nueva (PRECE, 2014 p. 11). ${ }^{17}$

É certo que o trabalho de Cochet em distintas frentes de luta encontra-se refletido em seus escritos, cujas linhas costuram afinidades estéticas na representação de duas guerras da Espanha, a de Independência e a Guerra Civil Espanhola. Daí que essa convergência, exposta no Diario, encontre-se também na produção do pintor argentino durante os anos de 1936 a 1939, como na gravura intitulada Qué corage! (Figura 2):

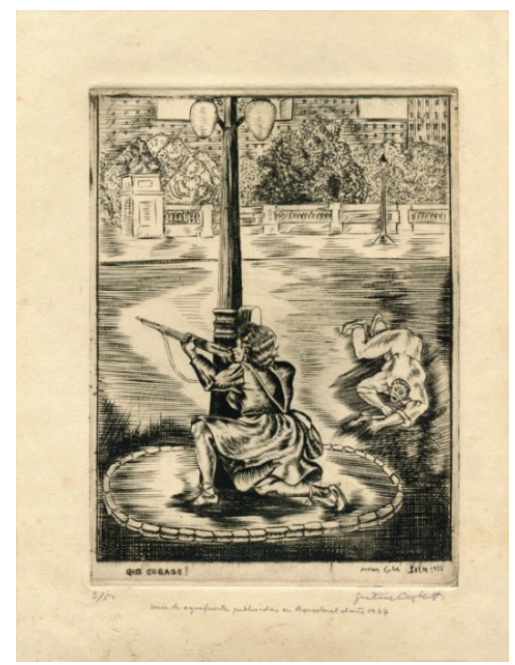

Figura 2. Reprodução da gravura Qué corage! (COCHET, 1936).

Fonte: Imagem cedida pelo Museo Gustavo Cochet.

Na gravura vemos, em uma praça, que uma miliciana está prestes a disparar contra o inimigo a fim de proteger um camarada ferido, que se arrasta no lado direito da gravura. Curiosamente, a cena ao redor é plácida, há árvores viçosas ao fundo, que inspiram calmaria. No entanto, o vazio da praça, com apenas os dois milicianos, expõe a configuração do confronto

${ }_{17}$ "Gustavo Cochet foi o presidente da Seção de Belas Artes da Confederação Nacional de Trabalhadores (CNT), organização anarcossindicalista, pertencente à Federação Anarquista Ibérica (FAI). Seu compromisso com o momento histórico o situou em um trabalho dirigido para uma mudança transcendente, promovendo o livre pensamento, a conscientização da unidade e solidariedade entre os homens como único caminho para construir uma sociedade nova." 
pela ausência de civis. A concentração dos sulcos está dirigida à miliciana e ao entorno do ferido, proporcionando dramatismo à imagem. Observa-se que a figura feminina está de costas para o espectador, e a expectativa pelo momento do disparo e do embate carrega a estampa de tensão.

Essa gravura é um exemplo acabado de uma estratégia para manter o ânimo durante a contenda, na qual ninguém poderia eximir-se do combate. Ao representar distintas pessoas, de diferentes ocupações e gêneros, pretendia-se nutrir a resistência na defesa pela República.

Cuando el artista está ante el bello rostro de una mujer, aterciopelado como la piel de durazno, o bien ante el encantamiento del paisaje, todo para él es poesía, amor y belleza; pero si bien al artista no tiene la culpa de que los hombres pero que fieras se aniquilen entre sí, no puede tampoco ignorarlo y si en medio del paisaje que él tanto admira, sus hermanos luchan y mueren, la armonía y la placidez se transforman en gritos de guerra y bravura. Cuando un pueblo está en armas, no ha de excluirse nadie y la voz del artista ha de tener el mismo acento del clarín de combate y no el de la flauta del pastor (COCHET, 1941, p. 24)..$^{18}$

No rastro da representação dessa figura da mulher destemida, é possível que Cochet tenha recorrido a algumas gravuras goyescas da série de Los desastres de la guerra - em que a mulher aparece com um forte caráter aguerrido -, tais como em Qué valor! (Figura 3), título que a gravura de Cochet repercute, e Y son fieras! (Figura 4):

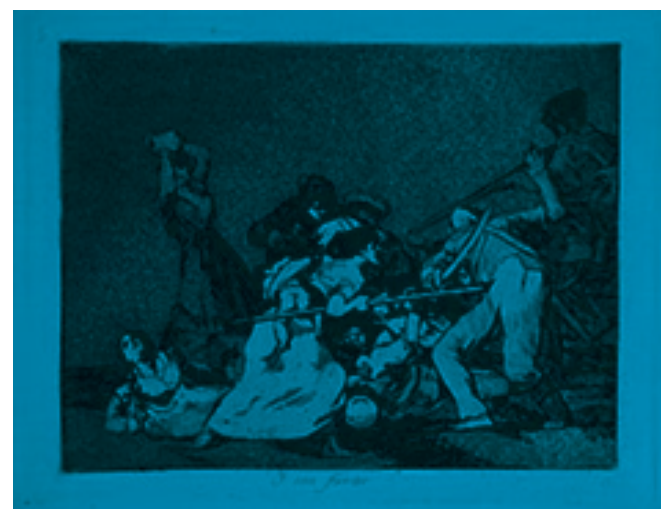

18 "Quando o artista está diante do belo rosto de uma mulher, macio como a pele de um pêssego, ou diante do encanto de uma paisagem, tudo para ele é poesia, amor e beleza; mas se, por um lado, o artista não tem culpa de que os homens como feras se aniquilem entre si, não pode tampouco ignorá-lo, e se, em meio da paisagem que ele tanto admira, seus irmãos lutam e morrem, a harmonia e a placidez se transformam em gritos de guerra e bravura. Quando um povo está armado, não há como excluir ninguém, e a voz do artista deve ter o mesmo toque do clarim de combate, e não o da flauta do pastor." 


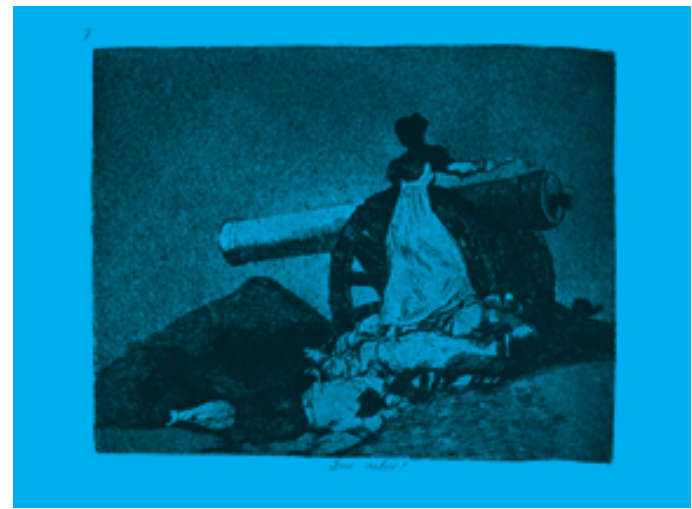

Figuras 3 e 4: Reprodução das gravuras Qué valor! e Y son fieras!, respectivamente (GOYA, 1810-1814). Fonte: Museo del Prado.

Por uma questão de espaço, não nos deteremos na análise das imagens goyescas, pois esse não é o objetivo deste artigo, mas podemos observar, brevemente, que em Qué valor!, Goya nos mostra a figura de uma mulher pronta a disparar um canhão contra o inimigo. A ação, certamente, situa-se no primeiro sítio a Saragoça, durante a invasão napoleônica, na Guerra de Independência, em que as mulheres se destacaram em uma ação destemida diante dos imprevistos. Naquele momento, a defesa das portas da cidade estava confiada, em grande medida, à artilharia, mas já nos primeiros ataques franceses, a artilharia caiu e, entre os dias $12 \mathrm{e}$ 15 de julho de 1808, alguns canhões foram alimentados e disparados por mulheres. O clima era de entusiasmo pela defesa da pátria, com homens e mulheres que resistiam com bravura, e rapidamente foram decantando-se figuras emblemáticas, tanto no meio militar, como no civil. Neste, a heroína popular por excelência foi Agustina Aragón e, seguramente, é com a figura dela que Goya identifica a imagem. Com similar valor, combatem as figuras femininas de $Y$ son fieras!, que com vigor e com o que têm às mãos - pedras, lanças - lutam contra soldados franceses armados com carabinas. À desvantagem em número e armamentos, impõe-se a coragem.

Em uma confluência estética, tanto nas imagens goyescas como nas estampas de Cochet, percebemos que, entre gestos contidos e largos, os gravadores vão construindo um universo no qual a proximidade dá o tom de catástrofe e nos mostra o absurdo do conflito em si, em que ferocidade e barbárie se confundem com a resistência. E nesse cenário a mulher merece 
um papel proeminente, seja como heroína, seja como vítima, revestida de contornos simbólicos ou realistas.

Essa relevância da figura feminina pressupõe dois movimentos do pensamento de Cochet (1941, p. 127): por um lado, revela um desejo igualitário e, por outro, expõe o rechaço a discursos doutrinários e impositivos, insistentemente assinalados em seu diário:

No creo en teorías o doctrinarios porque al final, las doctrinas se vuelven leyes que hay que imponerles por la fuerza. He comprobado en España para qué servían las normas establecidas de antemano, en los casos imprevistos, en que era necesaria la libre y espontánea iniciativa, yo he comprobado para qué sirve la libre iniciativa, para crear las más grandes cosas, porque el hombre no hará nunca cosa alguna, con tanta pasión, con tanto entusiasmo, con tanta fe, que cuando conscientemente obedezca sólo a su propia razón.

Por eso creo que la anarquía, mientras anarquía no sea doctrina ni principio estático, sino fuente inagotable para crear conciencias libres. ${ }^{19}$

Como se vê, o espírito livre e insubmisso de Cochet será o grande vetor de suas ideias e, pode-se dizer, guiará sua produção pictórica. Seu diário e suas gravuras estão delineados por frases curtas, que ora aparecem configuradas pelas situações e reflexões a respeito da guerra, ora pela necessidade de expor uma visão lúcida sobre a conjunção texto-imagem: "Los asuntos de mis cuadros no obedecen a una ideología doctrinaria, sino a que están em mi ambiente, porque vivo entre el pueblo y soy del pueblo" (COCHET, 1941, p. 9)..$^{20}$

Tal configuração impõe uma organização textual e pictórica que desobedece qualquer relação de causa e efeito, instaurando uma estética do estilhaço em sua escritura e gravura. E essa estética, acreditamos, tangencia as ponderações de Adorno em torno à natureza fragmentária do ensaio, pois Cochet (1941, p. 94), com o movimento fraturado de suas ponderações éticas e estéticas, pensa um momento histórico contundente, marcado pela reflexão artística desobediente a hierarquias canônicas:

\footnotetext{
${ }_{19}$ "Não acredito em teorias ou doutrinas porque, no final das contas, as doutrinas se tornam leis que se impõem por força. Comprovei na Espanha para que serviam as normas estabelecidas de antemão, nos casos imprevistos, em que era necessária a livre e espontânea iniciativa, eu comprovei para que serve a livre iniciativa, para criar as maiores coisas, porque o homem não fará nunca coisa alguma, com tanta paixão, com tanto entusiasmo, com tanta fé, como quando conscientemente obedeça somente à sua própria razão. /Por isso creio que a anarquia, enquanto anarquia, não seja doutrina nem princípio estático, mas fonte inesgotável para criar consciências livres."

20 "Os assuntos de meus quadros não obedecem a uma ideologia doutrinária, mas ao fato de estarem em meu ambiente, porque vivo entre o povo e sou do povo."
} 
No creo en el cubismo, en el surrealismo, ni en ningún ismo, creo que todo artista que se encasilla en una fórmula, no estará nunca a la altura de su propio talento, con el agravante de que cada vez lo estará menos, a medida que mayor sea su talento. ${ }^{21}$

Esse rechaço à categorização de sua arte reflete-se em seus exercícios de desobediência na composição pictórica, como na gravura intitulada 19 de julio (Figura 5):

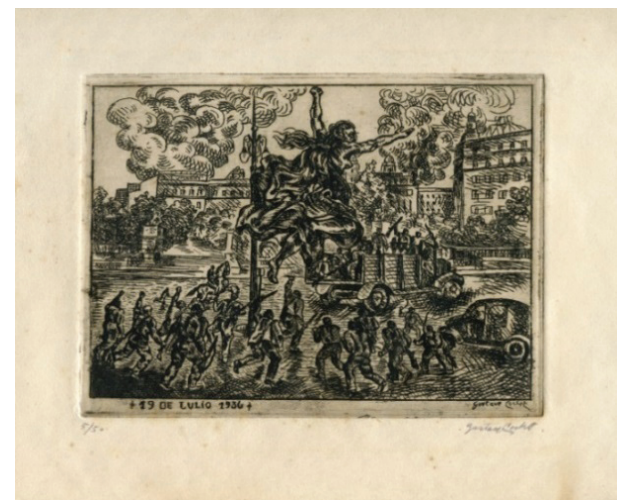

Figura 5. Reprodução da gravura 19 de julio (COCHET, 1936).

Fonte: Imagens fornecidas pelo Museo Gustavo Cochet.

Como vimos anteriormente, a data marca um momento de inflexão na escritura e na opção artística de Cochet, afinal, seu diário indica o dia 19 de julho como o início de sua composição escrita, bem como o momento em que "morre" o pintor para que nasça o "gravador-miliciano". Portanto, a estampa cumpre um papel fundamental para a compreensão do andamento da guerra e das escolhas cívicas e artísticas do pintor, daí que valha a pena analisá-la brevemente.

Ao observarmos a estampa, divisamos uma cena de guerra que, aparentemente, aglutina todos os elementos necessários para a representação de um fato histórico em sua referencialidade: um bombardeio, chamas e fumaça cobrindo todo o fundo da paisagem urbana, correria, homens agitando armas e um cavalo empinando, como signo de desabalada carreira. Em toda a cena há uma verticalidade das imagens que evoca um certo tom épico.

A esses elementos se une o título da gravura, que alude à data em que centenas de trabalhadores se concentraram na praça Catalunha, de

\footnotetext{
${ }_{21}$ "Não acredito no cubismo, no surrealismo, nem em nenhum -ismo, acredito que todo artista que se enclausura em uma fórmula, não estará nunca à altura de seu próprio talento, com o agravante de que cada vez o estará menos, à medida que maior seja seu talento.”
} 
Barcelona, nos primeiros momentos de eclosão do conflito, a fim de pedir armas ao presidente da Generalitat, Lluis Companys. Em meio ao pedido, Companys discursou, e os relatos históricos atestam que o anúncio do avanço das tropas nacionalistas em território catalão surgiu como uma bomba em praça pública. Como resposta, a população espalhou-se por toda a cidade em busca de armamentos para defender a capital, cujo cerco durou até janeiro de 1939.

Simultânea à tomada desse território ao final da contenda, viria a crítica ácida de Cochet (1941, p. 93) ao governo catalão, assinalada em seu diário:

La caída de Barcelona se juzgará claramente y con justicia cuando se conozca el heroísmo sin par, la abnegación nunca superada de los obreros de las fábricas catalanas [...] Cataluña fue la fuente inagotable en hombres, material, abastecimiento general. Barcelona cayó sin gloriosa lucha, pero no por falta de fiero coraje ni valor, pues su gloria es la de haber contribuido más que nadie a la resistencia sin lo cual no habría sido posible. ${ }^{22}$

A convergência dessa cronologia, que une o elogio à coragem dos catalães, no título da gravura, à contextualização de um acontecimento, parece conceder-nos a construção de um fato histórico na plenitude de seu efeito do real. No entanto, a gravura nos mostra que o artista não se limitou a conceber uma cena em que o elemento anedótico prevaleça, pois, na forma e sentido dela, Cochet introduz personagens e proporções que rompem com a representação literal e com a noção panorâmica de campo de batalha. Lembrando-nos de que a série não se revela pela leitura histórica literal, mas sim por uma composição erigida entre a imaginação e a história.

O primeiro exercício de ruptura com a literalidade histórica repousa na personagem feminina: trata-se de uma figura de grandes dimensões atestada pela altura do poste ao seu lado -, que flutua no centro da cena de guerra. Com sua farta cabeleira e o punho erguido, ela guia e incita um grupo de civis à luta. A profusão de traços em negro concede movimento e potência aos cabelos, ao vestido e aos gestos da jovem, e seu gigantismo confere um caráter simbólico e de matiz romântico ao combate. Por sua vez, a abundância de personagens, de cenas e ações concomitantes,

\footnotetext{
22 "A queda de Barcelona se julgará claramente e com justiça quando se conheça o heroísmo sem par, a abnegação nunca superada dos operários das fábricas catalãs [...] Catalunha foi a fonte inesgotável em homens, material, abastecimento geral. Barcelona caiu sem gloriosa luta, mas não por falta de feroz coragem nem valor, pois sua glória é a de ter contribuído mais que qualquer um à resistência, sem a qual não teria sido possível."
} 
aliada aos jogos de claro-escuro, imprimem à cena a sensação do caos do combate em praça pública.

Dinamismo, simultaneidade e proximidade nos levam à constatação do abandono da preocupação clássica pela relação plano/fundo, pois tanto a performance da mulher, quanto a dos trabalhadores espelham-se no gesto do braço em riste, cuja verticalidade se precipita rumo à contenda, criando uma imagem fixada por duas instâncias: a preocupação pelo caráter simbólico da cena e a necessidade de eternizar imageticamente um momento histórico de dimensões quase épicas:

Si el artista se limita al hecho puramente cronológico, literario y anecdótico, es más bien un cronista; para el verdadero artista, su gran arte, no admite los hechos sino recién cuando pasan a ser leyendas (COCHET, 1941, p. 69). ${ }^{23}$

Em sua elaboração de traços épicos, a gravura 19 de julio ressalta a importância da representação de múltiplas facetas da mulher na guerra, como pudemos verificar na gravura Qué corage! (Figura 2). Tal inclinação abrangente estará registrada tanto no diário do autor, como em sua série, pela qual desfilam diversos perfis femininos: de bravura, de solidariedade, mas também de envilecimento, como na imagem da gravura iiArriba, España!! (Figura 6):

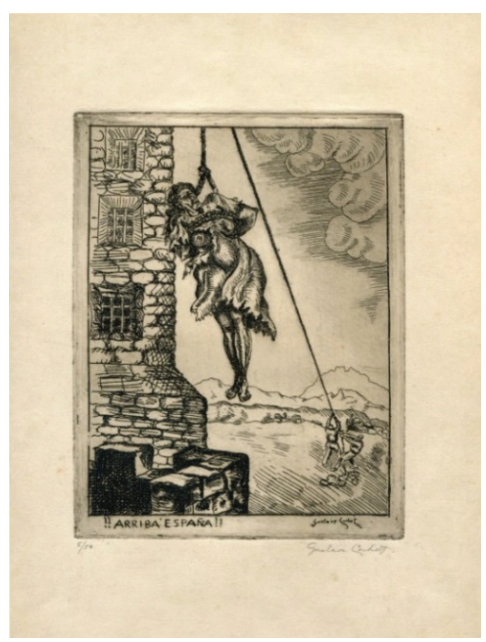

Figura 6. Reprodução da gravura iiArriba España!! (COCHET, 1936). Fonte: Imagem cedida pelo Museo Gustavo Cochet.

${ }_{23}$ "Se o artista se limita ao fato puramente cronológico, literário e anedótico, ele está mais para um cronista; para o verdadeiro artista, sua grande arte não admite os fatos senão quando acabam de tornar-se lendas." 
Na estampa, a destreza de Cochet se reflete na precisão do traço e no domínio da técnica de água-forte pela distribuição de luzes no jogo de claro-escuro da estampa. Ao fundo da cena, em segundo plano, vemos homens que "içam" uma mulher junto ao que parece ser uma torre de um castelo ou forte. A figura traja um vestido em frangalhos, suas partes íntimas estão expostas e seus pés e mãos, atados. A concentração dos traços da composição acumula-se na mulher, o que acentua sua expressão de dor e, por contiguidade, exibe as crueldades cometidas com seu corpo, que parece ter sido violado e agora é oferecido em humilhação pública. Seu rosto inclinado, com o olhar dirigido para os céus, indica que ainda está viva, apesar do desalento e da agonia. A figura, por sua dimensão, cabeleira e vestido, evoca a representação alegórica do capricho 19 de julio (Figura 5). Mas a mulher, antes destemida, agora aponta para a derrota e o ultraje, configurando, talvez, o momento em que a República começava a perder a guerra.

A esse quadro degradante se soma a ironia do título, que ao mesmo tempo que resgata a saudação fascista entoada pelo bando nacionalista ( ii Arriba España!!), ${ }^{24}$ joga com o duplo sentido dos verbos "içar” [izar] e "alçar" [alzar]. De modo que podemos ler na imagem a alegoria de uma Espanha republicana subjugada e humilhada. O braço bravio da estampa anterior é substituído pelo içar de corpos degradados e coisificados, como uma das mais terríveis consequências da guerra: a ação vingativa face ao outro:

¿Sabéis lo que es más terrible en la guerra? No es con seguridad la bomba que destruye hogares, aniquila niños, siembra la muerte doquier. Con serlo tanto, la guerra tiene su ley inexorable. No, lo más terrible es el odio y la venganza, el enceguecimiento de la venganza sobre el vencido. Nada más repelente y contrario a todo sentimiento humano. ¡No puedo creer que después de cerca de dos años, todavía siguen asesinando y sacrificando sus víctimas, vencidas y anonadadas! (COCHET, 1941, p. 102). ${ }^{25}$

\footnotetext{
${ }^{24}$ Vale a pena lembrar que, à medida que as tropas nacionalistas iam avançando sobre o território republicano, durante o decorrer da guerra, governos locais eram constituídos em distintas instâncias: política, militar e inclusive burocrática. Uma prova dessa organização do exército nacionalista era a presença obrigatória do emblema ¡Arriba España!, que constava em toda documentação tramitada na época nesses territórios tomados.

25 "Sabem o que é mais terrível na guerra? Não é com certeza a bomba que destrói lares, aniquila crianças, colhe a morte em qualquer lugar. Por ser assim, a guerra tem sua lei inexorável. Não, o mais terrível é o ódio e a vingança, a cegueira da vingança sobre o vencido. Nada mais repelente e contrário a todo sentimento humano. Não posso crer que
} 
Essa clarividência em relação ao fim da contenda e seus efeitos colaterais e prolongados nos aproxima da natureza miúda do diário, cuja reflexão se expressa através do abandono da grandiosidade com o intuito de deslindar pequenos testemunhos, extraídos irregularmente, por conta do movimento fragmentário e assimétrico de sua narrativa.

E é a partir desse movimento peculiar que podemos pensar o diário de Cochet como um conjunto de "aforismos ensaísticos", que giram ao redor de dois grandes objetos: a reflexão sobre o papel do artista e de sua arte frente a um mundo em crise, e a reivindicação de posições claras nesses dois âmbitos, o da estética e o da ética. Nesse caminho de mão dupla, a experiência emerge como um elemento central para que a articulação se concretize:

\begin{abstract}
A relação com a experiência - e o ensaio confere à experiência tanta substância quanto a teoria tradicional às meras categorias - é uma relação com toda a história; a experiência meramente individual, que a consciência toma como ponto de partida por sua proximidade, é ela mesma mediada pela experiência mais abrangente da humanidade histórica; é um mero autoengano da sociedade e da ideologia individualistas conceber a experiência da humanidade histórica como sendo mediada, enquanto o imediato, por sua vez seria a experiência de cada um (ADORNO, 2008, p. 26).
\end{abstract}

No interior dessa figuração de Cochet, sua escritura, muito próxima à oralidade, retoma grandes questões, tais como a necessidade de admitir as atrocidades cometidas pelo ser humano, o reconhecimento público de um acontecimento trágico e a constatação do caráter irreparável dos acontecimentos da Guerra Civil Espanhola e suas sequelas durante o pós-guerra. Encravada nessas ponderações, a escritura do diário irradia posturas ideológicas, enfrentamentos artísticos e históricos e um diálogo contundente com a tradição. Nesse caso, com os desastres goyescos:

Así como los espejismos en el desierto nos hacen ver lo que no existe, nuestra imaginación cree ver monstruos gigantes, en las siluetas de las montañas o cuerpos humanos torturados en los troncos de los árboles. Así la verdad en el arte no dependerá nunca de una realidad convencional, sino de la que emerge desde el fondo del alma del artista (COCHET, 1941, p. 105) ${ }^{26}$

depois de cerca de dois anos, ainda continuam assassinando e sacrificando suas vítimas, vencidas e insignificantes!"

26 "Assim como as miragens no deserto nos fazem ver o que não existe, nossa imaginação crê ver monstros gigantes, nas silhuetas das montanhas ou corpos humanos torturados nos troncos das árvores. Assim a verdade na arte não depende nunca de uma realidade convencional, mas daquela que emerge do fundo da alma do artista." 


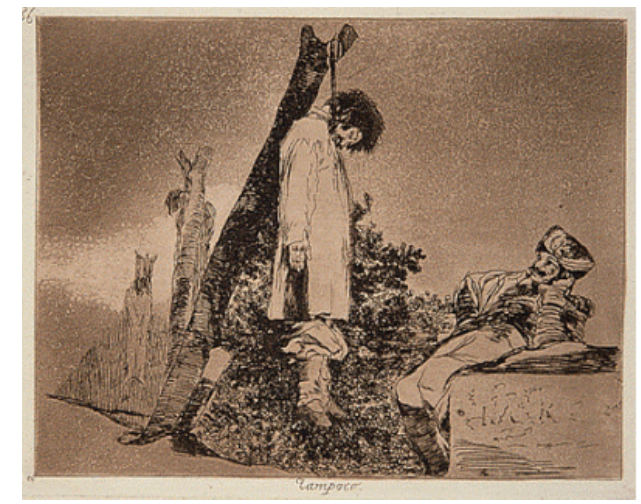

Figura 7. Reprodução da gravura Tampoco (GOYA, 1810-1814).

Fonte: Biblioteca Nacional de Madri.

Como na imagem de Cochet, na estampa goyesca Tampoco (Figura 7), não se vê a contorção desesperada do ente pendurado. Tudo ali é insuportavelmente calmo: um soldado francês contempla um cadáver pendurado com as calças arriadas, em uma situação de dupla humilhação, tal qual a mulher violada na composição dos anos 1930.

A gravura evoca uma prática comum durante a Guerra de Independência: o enforcamento de espanhóis ao léu tinha a função de advertir aqueles que pensassem em rebelar-se contra o invasor francês. A contundência do ato exprime-se em planos distintos: no olhar complacente do soldado, no corpo pendurado em primeiro plano e na fileira de cadáveres suspensos em uma linha que se prolonga a perder de vista.

Na transfiguração do corpo mutilado e vexado, Cochet encontra-se esteticamente com o gravador espanhol para representar as atrocidades da guerra, como em i¡Arriba, España!!. Como em Goya, há na produção do gravador argentino uma negativa frente ao anedótico para privilegiar a conformação da guerra em seu aspecto cotidiano, em que o horror toma conta das ações humanas e recompõe-se em qualquer lugar e momento:

Un susto: estábamos reunidos alrededor de una larga mesa profesores de la Universidad, pintores, músicos, escultores, literatos; unos quince aproximadamente. A los primeros disparos del Cervera que bombardeaba la ciudad, nos encontramos todos sin excepción, bajo la mesa, como si lo hubiésemos convenido de antemano con perfecta unanimidad. El silbido de los obuses nos llenó de terror, los sentíamos venir silbando con la clara sensación de que iban a estallar sobre nosotros. Era al principio de la guerra. Todavía no 
estábamos bastante fogueados. Pasada pues la primera impresión, encendimos algunas velas y continuamos la sesión.

Barcelona, marzo de 1937 (COCHET, 1941, p. 23).27

Em uma aproximação desmedida, em que a violência se introduz em close-up, Cochet reaviva a natureza do combate na Guerra Civil Espanhola: um conflito que se havia transformado, em seu decorrer, em uma guerra de guerrilhas, em uma guerra total em sua espacialidade. Para dar conta do aturdimento causado por essa fragmentação espacial, Cochet escreve um diário repleto de rupturas e compõe gravuras hierarquicamente insolentes. Com essas composições, o pintor busca abolir qualquer ideia de causa e efeito e aproximar o leitor/espectador a diferentes ambientes da contenda. Ao expor as atrocidades da guerra, Cochet converte suas estampas em campos semânticos de perda de vidas, estas, anônimas ou não, transfiguram-se em cantos veementes, comprometidos com uma causa que perdura no presente.

Yo no podré nunca ser fascista porque: los millares de seres que murieron en España, donde tuvo lugar la primera resistencia seria que se le hizo al fascismo, murieron con un heroísmo y una valentía sin par. Yo con todas mis fuerzas, con toda mi alma, con todas mis ansias y exponiendo también mi vida durante tres años y sin ninguna duda, sin ninguna vacilación, estuve con ellos entregándome por entero.

No podré, pues, nunca traicionar su memoria, y, por lo tanto, mi corazón sigue igualmente al lado de los que aún sufren con los que son todavía sacrificados por el salvaje odio y venganza del vencedor (COCHET, 1941, p. 52). ${ }^{28}$

${ }_{27}$ "Um susto: estávamos reunidos ao redor de uma longa mesa, professores da Universidade, pintores, músicos, escultores, literatos; uns quinze aproximadamente. Aos primeiros disparos do Cervera, que bombardeava a cidade, encontramo-nos todos, sem exceção, debaixo da mesa, como se tivéssemos combinado de antemão com perfeita unanimidade. O som do bombardeio nos encheu de terror, sentíamos vir assoviando com a clara sensação de que iam explodir sobre nós. Era no começo da guerra. Ainda não estávamos bastante acostumados. Passada, pois, a primeira impressão, acendemos algumas velas e continuamos a sessão. /Barcelona, março de 1937."

28 "Eu não poderei nunca ser fascista porque: os milhares de seres que morreram na Espanha, onde teve lugar a primeira resistência séria que se fez contra o fascismo, morreram com um heroísmo e uma valentia sem par. Eu, com todas as minhas forças, com toda a minha alma, com todas as minhas ânsias e expondo também minha vida durante três anos e sem nenhuma dúvida, sem nenhum vacilo, estive com eles, entregando-me por inteiro. /Não poderei, pois, nunca trair sua memória, e, portanto, meu coração continua igualmente ao lado dos que ainda sofrem, com os que são, todavia, sacrificados pelo selvagem ódio e vingança do vencedor." 
Um diário entre o cívico e o estético: as reflexões de Gustavo Cochet, durante os anos da... - 852

Em Cochet esse canto se funda na palavra que pende entre a ponderação, a exigência feroz e o enxame verbal fragmentário, à moda de um ensaio de perfil aforístico:

Essai, conhecido em francês desde o século XII, provém do baixo latim exagium, a balança; ensaiar deriva de exagiare, que significa pesar.

Nas proximidades desse termo se encontra examen: agulha, lingueta do fiel da balança, e, por extensão, exame ponderado, controle. Mas um outro sentido de "exame" designa o enxame de abelhas, a revoada de pássaros.

A etimologia comum seria o verbo exigo, forçar para fora, expulsar, e daí exigir. Quantas tentações, se o sentido nuclear das palavras atuais devesse resultar do que elas significaram num passado longínquo! $O$ ensaio seria a pesagem exigente, o exame atento, mas também o enxame verbal cujo impulso se libera (STAROBINSKI, 2011, pp. 13-14).

Seguindo Starobinski, a escritura do pintor argentino "expele" em frases clarividentes suas reflexões sobre a guerra, a vida, a arte, e tal discernimento permite a Cochet (1941, p. 106) a possibilidade de ler a tragicidade espanhola:

España no es trágica porque sea de su natural; la belleza de su tierra, su lima, el carácter de las gentes que la habitan, etc., todo está predispuesto a la felicidad. La verdad es que España pues, la ha hecho trágica la inquisición, el chulo torero, el señorito y la Guardia Civil. ${ }^{29}$

Dentro da vida, dentro do texto eem sua arte, o compromisso de Cochet ressoa em palavras estilhaçadas, em parágrafos curtos, embaralhados no tempo e no espaço, num movimento que parece acompanhar o próprio fluir inconstante e irregular da memória de um tempo vivido e refletido.

Nesse fluir, em que suas visões recusam imposições categóricas, Gustavo Cochet construiu em sua escritura e em sua arte um testemunho que rechaça o esquecimento e reivindica uma posição ética e estética frente à palavra e à imagem, referentes a um tempo convulso e urgente, mas profundamente marcado por um ideal de liberdade.

29 "Espanha não é trágica porque seja de sua natureza; a beleza de sua terra, sua compreensão, o caráter das pessoas que a habitam etc., tudo está predisposto à felicidade. A verdade é que a Espanha, portanto, a tornaram trágica a inquisição, o gracioso toureiro, o filhinho de papai, a Guarda Civil." 
Remate de Males, Campinas-SP, v. 37, n. 2, p. 827-854, jul./dez. 2017 - 853

\section{REFERÊNCIAS}

ADORNO, Theodor. O ensaio como forma. In: Notas de literatura I. São Paulo: Duas Cidades / Editora 34, 2008, pp. 23-39.

BERARDINELLI, Alfonso. A forma do ensaio e suas dimensões. Remate de Males, Campinas, v. 31, n. 1-2, jan.-dez., 2011, pp. 25-33. Disponível em: <http://periodicos. sbu.unicamp.br/ojs/index.php/remate/issue/view/375>. Acesso em: 28 jan. 2017.

BLANCO AGUINAGA, Carlos et al. Historia social de la literatura española. Tomos II y III. Madrid: Castalia, 1979.

COCHET, Gustavo. Catálogo Gustavo Cochet. Caprichos. Estampas 1936/1938. Santa Fe: Museo Gustavo Cochet, 2014.

COCHET, Gustavo. Diario de un pintor. Con treinta y siete grabados impresos con el taco original. Buenos aires: Ediciones Conducta, 1941.

COCHET, Gustavo. Qué corage! Funes, Julio de 1936. Água-forte, 19,8 x 14,5 cm.

COCHET, Gustavo. Mis caprichos... Funes, Julio de 1936. Água-forte, 19,6 x 14,5 cm.

COCHET, Gustavo. 19 de julio. Funes, 1936. Água-forte, 14,6 x 19,7 cm.

COCHET, Gustavo. ¡iArriba España!! Funes, 1936. Água-forte, 19,8 x 14,7 cm.

GOYA Y LUCIENTES, Francisco José de. Anuncio de venta. Diario de Madrid, 1799, [s.p.]. (Cópia microfilmada)

GOYA Y LUCIENTES, Francisco José de. Qué valor! (n. 7). Madri, 1810-1814. Água-forte. $15,5 \times 20,6 \mathrm{~cm}$.

GOYA Y LUCIENTES, Francisco José de. Y son fieras (n. 5). Madri, 1810-1814. Água-forte, $15,5 \times 20,9 \mathrm{~cm}$.

GOYA Y LUCIENTES, Francisco José de. Tampoco (n. 39). Madri, 1810-1814. Água-forte, $15,7 \times 20,8 \mathrm{~cm}$.

HOUAISS, Antonio. Dicionário Houaiss da língua portuguesa. Rio de Janeiro: Objetiva, 2009.

KARP LUGO, Laura. Los caprichos de Gustavo Cochet, memorias de la Guerra Civil. Amnis (on ligne), n. 2, 2011. Disponível em: <2011.http://amnis.revues.org/1506>. Acesso em: 15 jan. 2017.

LAFUENTE FERRARI, Enrique. Desastres de la Guerra y dibujos preparatorios. Barcelona: Central Hispano2, 1982.

MACHADO, Antonio. Campos de Castilla. Madrid: Cátedra, 2002. 
Um diário entre o cívico e o estético: as reflexões de Gustavo Cochet, durante os anos da... - 854

MACHADO, Antonio; MACHADO, Manuel. Juan de Mairena. In: Obras completas. Madrid: Juventud, 1973, pp. 702-844.

MACHADO, José Pedro. Dicionário etimológico da língua portuguesa. 5 v. $3^{\text {a }}$ ed. Lisboa: Livros Horizonte, 1977.

PERRONE-MOISÉS, Leyla. Escolher e/é julgar. Revista Colóquio/Letras, Ensaio, n. 65, jan. 1982, pp. 5-13. Disponível em: <http://coloquio.gulbenkian.pt/ bib/ sirius.exe/ getrec?mfn=2911\&_template=singleRecord $>$. Acesso em: 16 jan. 2017.

PRECE, María Eugenia (org.). Gustavo Cochet: Caprichos. Estampas 1936-1938. Santa Fe: Espacio Santafesino Ediciones, 2014[2013].

RICO, Francisco (org.). Historia y crítica de la literatura española. Tomos 7, 8 e 9. Barcelona: Grijalbo, 1981.

RUEDA, Manuel de. Instrucción para gravar en cobre. Edición facsímil. Reed. Granada: Universidad de Granada, 1991[1761].

PÉREZ SÁNCHEZ, Alfonso \& SAYRE, Eleanor A. Goya y el espíritu de la ilustración. Madrid: Museo del Prado, 1988.

SÁNCHEZ, Eleanor A. Goya y el espíritu de la ilustración. Madrid: Museo del Prado, 1988.

STAROBINSKI, Jean. É possível definir o ensaio?. Remate de Males, Campinas, v. 31, n. 1-2, jan.-dez. 2011, pp. 13-24. Disponível em: <http://periodicos.sbu.unicamp.br/ ojs/ index.php/remate/issue/view/375>. Acesso em: 28 jan. 2017.

TUÑON DE LARA, Manuel. La España del siglo XX. 3 v. Barcelona: Laia, 1974. 